Bond University

Research Repository

\title{
Reading Václav Havel in the Age of Trump
}

\author{
Brennan, Daniel
}

Published in:

Critical Horizons

DOI:

10.1080/14409917.2019.1563997

Licence:

Free to read

Link to output in Bond University research repository.

Recommended citation(APA):

Brennan, D. (2019). Reading Václav Havel in the Age of Trump. Critical Horizons, 20(1), 54-70.

https://doi.org/10.1080/14409917.2019.1563997

\section{General rights}

Copyright and moral rights for the publications made accessible in the public portal are retained by the authors and/or other copyright owners and it is a condition of accessing publications that users recognise and abide by the legal requirements associated with these rights.

For more information, or if you believe that this document breaches copyright, please contact the Bond University research repository coordinator. 


\section{Reading Václav Havel in the Age of Trump}

Recently, and mainly around Donald Trump’s election victory, analysts have been busy proclaiming the return of authoritarian politics. ${ }^{1}$ In response to these dark times, it thus seems natural to turn to books from thinkers who resisted previous incarnations of totalitarianism. Hence, there has been a renewed interest in the work of Czechoslovakian dissident-then-President Václav Havel, whose thoughts on opposing the dishonesty of totalitarian regimes with effortful honesty - what he termed living in truth seems like a useful remedy for addressing the current predicament. ${ }^{2}$ The following segment from an article in The New Yorker is illustrative of the renewed interest in Havel.

The recent political earthquakes have found us intellectually and emotionally underprepared, even helpless. None of our usual categories (left, right, liberal, conservative, progressive, reactionary) and perspectives (class, race, gender) seem able to explain how a compulsive liar and serial groper became the world's most powerful man. Turning away from this unintelligible disaster, many seek enlightenment in literary and philosophical texts from the past, such as Hannah Arendt's “The Origins of Totalitarianism,” George Orwell’s “1984,” and Sinclair Lewis’s “It Can’t Happen Here.” It may be more rewarding, however, to turn to Václav Havel: a writer and thinker who intimately experienced totalitarianism of the Orwellian kind, who believed that it had already happened in America, and who also offered a way to resist it. ${ }^{3}$

It seems timely then to offer an analysis of some nuances of Havel's thoughts on resistance which might be contemporaneously pertinent. A close reading of Havel is important because in looking too quickly at Havel's thoughts on dissent one might miss important lessons in Havel's work, or worse, misinterpret his thoughts on resistance. To put it bluntly, The New Yorker article describes Havel's notion of the parallel polis, a concept that promotes the creation of a society of dissident who live underground and alongside

\footnotetext{
${ }^{1}$ See, for example, Salhani, "Experts in Authoritarianism"; Brader, "Pelosi"; Ben-Ghiat, "Trump Authoritarian Playbook"; Ben-Ghiat, "Trump's Authoritarian Politics".

2 See, for example, Mishra "Vaclav Havel's Lessons".

${ }^{3}$ Ibid.
} 
an authoritarian regime. Havel was somewhat supportive of the idea but ultimately rejected it claiming that it was important not to run away from political reality. It was Václav Benda who championed the idea of creating a society of dissidents alongside that of an oppressive regime. Such a misreading is symptomatic of other articles which suggest that Havel's thought is useful for finding some way to combat oppression in the age of Trump.

A prominent but subtle theme throughout Havel's oeuvre is a self-deprecating humility which reveals a strong anti-messianic message which is often overlooked in discussions of Havel's significance as a thinker on resistance. It is this that I will focus on in this paper as it is of vital importance for understanding Havel's importance for addressing today’s political woes. Havel is not a thinker arguing for a revolution, nor is he arguing for small gradual progress that would overthrow Trump either. Havel always resists any messianic message for overthrowing evil and instead advocates an introspection on the morality of one's own behavior. That is, Havel, as a critic of totalitarian politics is more interested in how such politics convinces individuals to act against what a properly reflected upon moral intuition would suggest. Havel is an advocate of individual responsibility rather than collectively organized resistance against a regime. Havel hopes for a situation where individuals ask themselves what their actions mean for the creation of or sustenance of detrimental social situations. Where Terence Renaud has argued that genuine resistance today must revisit the explanation of resistance as an activity of the underground, Havel advocates changes in personal behavior in the light of day. ${ }^{4}$ Thus, Havel is antithetical to most contemporary theories of resistance which have at their base a utopian dream. John Gray has effectively criticized utopian projects as justifying violence as the creation of apocalyptic progress. ${ }^{5}$

Havel's self-deprecating reflections about his physiological and moral failings suggest that he would today claim that he is not the savior from the post-truth world - and in my reading, this is the most important reason to read Havel today. Havel's work continually asserts the dangers of any political theory which rests on messianic foundations as a moral address to oppressive politics. Perhaps the most prescient insight in Havel's work is his continued claim that his analysis of what he termed posttotalitarianism, was as applicable to Western politics as it was to the late socialist predicament. Havel's

\footnotetext{
${ }^{4}$ Renaud, "Going Underground"

${ }^{5}$ Gray Black Mass, 47.
} 
thoughts on moral behavior are thus not suddenly relevant, if anything they demonstrate how much we should have been reading him when we thought things were going well. It is important to note that the sentiment attached to the sudden interest in Havel, seems to take root in a desire to return the world to how it was before Trump became President. It is as if the proliferation of post-truth behavior snowballs out of Trump's unorthodox campaign in the Republican presidential primaries. It is my claim that a reading of Havel, if a tonic for anything, is a cure for this mistaken assumption. Trump, and the politics associated with the current world situation, did not suddenly emerge, Havel's self-deprecation and distrust of grand narratives of resistance point out that citizens voted for Trump in numbers significant enough to win an election. Havel's resistance, rather than taking to the streets to proclaim 'not my President', asks citizens to individually ask themselves why did he win and to change their behaviors which contributed to that situation. ${ }^{6}$ In the wash u

In Havel's first major speech as President, he claimed that the blame for the evils perpetrated by the totalitarian regime were the fault of each and every citizen who in some way acted in a manner which supported the system. Thus, a political hero is not the appropriate response to authoritarianism.

Effectively Havel claims that a political situation is not the result of the whims of some individual's program, but is instead the sum of civic behavior. Interestingly the boundary between private and civic behavior, in Havel's thinking is somewhat blurred. Even the conversations around the kitchen table, were for Havel, mortar for reinforcing the political ideology. Such a view, which is actually consistent with Havel's thought, is in contrast to interpretations of Havel which depict him as the political hero for our times and a savior of democratic politics. For example, Philip Zimbardo has argued that Havel is a hero that we should emulate. ${ }^{7}$ Zimbardo uses Havel as an emblematic hero for his not for profit organization The Heroic Imagination. ${ }^{8}$ Such work is, I will argue, antithetical to Havel’s actual project.

In this paper, I will focus on how Havel's self-deprecation offers a subtle but significant critique of western politics which promotes a virtue ethics of sorts instead of a blueprint for radical action. I will also explain the important and related critique of messianic politics entailed in Havel's thought.

\footnotetext{
${ }^{6}$ There are, as I write, 187077 members of the Facebook group, 'Donald Trump is not my President' https://www.facebook.com/groups/hillaryclinton2016president/

7 Zimbardo "Why the World needs Heroes".

${ }^{8}$ See the website, http://heroicimagination.org/
} 


\section{Havel's Humility}

Havel regularly and obviously goes to great lengths to resist any possible heroicizing of his activities. ${ }^{9}$ For example, consider Havel's choice to publish, in Letters to Olga, numerous correspondence devoted to the topic of the pain and suffering caused by his hemorrhoids. He writes, "My Hemorrhoids, fortunately, are quiescent; just now they’ve been bleeding a little, but perhaps nothing will come of it.” ${ }^{10}$ The collection of letters has been richly received for its difficult but important consideration of proper personal responsibility in dark times. In Letters to Olga we also find perhaps the clearest attempt to analyze and describe the driving idea of Havel's work, living in truth. It is also well known that the collection does not include all of Havel's correspondence to his wife. Thus, the inclusion of such a private mundane concern seems strange alongside the more obviously philosophical letters. The effect, however, is to resist any heroic interpretation of his imprisonment - and it is successful. Fourteen separate mentions of the discomfort caused by hemorrhoids are more than enough to stick in the mind of the reader. Havel presents himself in his human all too human condition as a flawed man with a flawed body. It isn't the case that Havel's publication of his hemorrhoid pain is an attempt to demonstrate the increased and prolonged suffering caused by his dissident activity - as if it were further evidence of how much he has sacrificed for the liberation of Czechoslovakia. The blunt, un-romanticized announcement of the details of the bleeding hemorrhoids resists that possibility.

Importantly, for this effect to manifest, one must read the entirety of the letters. Skipping over the mundane sections of the letters to find explicit calls for existential revolution would have the opposite effect. That is, a quick reading of the famously important letters, hides the lengths that Havel went to ensure that his legacy was remembered as that of an ordinary and flawed man. That a curated reading of Havel can give rise to such a different interpretation of his most important ideas is a good enough reason on its own to read Havel more closely because at the very core of Havel's thought is a struggle against heroic interpretations of human action. In Disturbing the Peace, a book length transcript of an interview

\footnotetext{
${ }^{9}$ According to Aung San Suu Kyi, Havel declined the nomination for the Nobel Peace Prize in 1991 nominating Ms Kyi instead. See, Bilefsky, "Havel Refused 1991 Nobel Prize"

${ }^{10}$ Havel, Letters to Olga 56.
} 
between Havel and Karel Hvížd'ala, Havel gives good indication of why it is important to avoid heroic interpretations of positive change.

... as soon as man began considering himself the source of the highest meaning in the world and the measure of everything, the world began to lose its human dimension, and man began to lose control of it... It seems to me that if the world is to change for the better it must start with a change in human consciousness, in the very humanness of modern man... It may seem like a paradox, but one I think will prove true, that only through directing ourselves toward the moral and the spiritual, based on respect for some "extramundane" authority - for the order of nature or the universe, for a moral order and its superpersonal origin, for the absolute - can we arrive at a state in which life... [has] a genuinely human dimension. ${ }^{11}$

For Havel, the hope of humanity lies in surrendering the authority for understanding its predicament to an "extramundane" source. That is, the horizon of possible human meanings of the world do not originate in the human. Affirming this is the first step for addressing a dire political situation. Significantly, Havel labels this enterprise a possible paradox - where to undertake the heroic task of rescuing humanity, humanity must recognize its non-heroic essence. This is far more than asserting some well-worn cliché like mankind's quest for natural domination through science is an expression of hubris. Instead what Havel means is that fundamentally, in our situatedness in the word, mankind's meaning from the perspective of nature shows the limits of our agency. That is, the natural world shows us just how much freedom we lack. The deliberate choice to publish letters about the travails of obtaining hemorrhoid cream are a well-crafted attempt to demonstrate the tight restrictions on the authors freedom. Havel sees himself not as the hero, but instead as an individual who acted as much as they were able in the specific circumstances he found himself in. By reminding the reader of his mundane concerns Havel does not offer his thought as a paradigm shattering insight into the human condition, instead the challenge is to offer a vision of political change that does not rely upon the grand gesture or martyrdom of a hero.

\footnotetext{
${ }^{11}$ Havel, Disturbing the Peace, 11-12.
} 
Perhaps the strongest example of Havel's anti-hero message is found in his least remarked upon offering, the 2011 film Leaving (Odcházení). ${ }^{12}$ The film is based on a play of the same name and depicts the story of a retiring president who is anxious at having to leave the luxuries of the presidential lifestyle. A good sense of the significance of Havel's self-deprecation can be discerned in the film's opening scene. The out-going President, Vilém Rieger, who is clearly in large part an autobiographical character, is being interviewed by a journalist for a newspaper. In preparation for the interview the president's wife tells him that he must tell the journalist what he really thinks or else the public will be disappointed. When the journalist arrives, he is for the most part only interested in having Reiger restate his commitment to positions he propounded in the past, and which are clearly Havel's own values, and which when restated out of context sound more like clichés than serious positions. The film is in the same absurdist style as Havel's plays and thus the effect of seeing a Havel like character attempt to neatly summarize his philosophical commitments is comical. Throughout the interview his advisors and wife remind him of what beliefs he has forgotten to mention. They also try to steer the interview so that the most positive article will result. The significance of this interview lies in the rapid destruction Havel initiates of the perception of his public persona. Reiger announces that people have tried themselves to believe in the values which he embodies, and as he announces this the character looks suspiciously pompous and inauthentic. The re-statement of well-rehearsed positions on the role of education on improving moral lives has the effect of reducing the president’s speech to cliché. Reiger and the journalist talk of their "roles" which only adds to the artificiality of the situation as if in announcing his humanist philosophy the president is performing a role rather than contributing meaningful conversation.

Following the interview Reiger asks his advisor why there were no questions about concrete political issues of the day. He is lamenting the perception that his ideas were a calcified relic, condensed into the sad clichés which fail to connect to the concrete political issues which (in Havel's case) they were supposed to address. This lament is continued in a later scene where Havel presumably is making a joke about his reception in academia. The scene introduces Bea, a devotee of Reiger's political writing, who happens to be an attractive young woman and who is an expert in sociolinguistic communications, and

\footnotetext{
${ }^{12}$ Odcházení
} 
who has written a thesis on Reiger’s work titled, 'Reiger’s Theory of Democracy'. Bea appears on her knees before Reiger as a swooning groupie. The effect not only lampoons academic hero worship of Havel but also bluntly ridicules the idea that Reiger (Havel's) ideas are coherent enough for close study in academia - a point Havel often made in his writing. The sexual advances of the young woman are a sarcastic representation of Havel's opinion on the hero worship of political figures. Reiger is receptive to her advances and his flirting is interpreted by Bea as a symbolic representation of some theoretical concept found in his writing. Yet Bea's emphatic theorizing on Reiger's work clearly excites the President - his ego is stroked by the advances and he lets himself think that his work is as important as she makes out. As a moment of self-deprecation Havel is not only removing the pedestal from underneath his writing, but even analyzing the authenticity of his humility. The only possible interpretation is that Havel is suggesting that he was a man of large self-estimation - a potentially contradictory assertion considering the effort with which Havel lampoons his self-esteem. The audience see the warts and all presentation of a man who is attracted to the young women, and is willing to use his fame to secure sexual favors - it is important to note that Havel made little secret of his extra-marital affairs. ${ }^{13}$ In my reading, Havel is pleading with the audience to see him for what is was, a morally difficult character and not the hero of the world.

The journalist's final question of the interview captures the severity of the self-deprecation Havel has produced. Reiger's answer is full of self-mockery as the scene darkens and an ominous wind blows across the table before he retorts, "they wouldn't dare.” A repeated trope in the film is the reluctance that Reiger and his family display to the prospect of leaving the comfort of the villa. If this is a character based on Havel, then Havel is clearly showing the Czech audience just how much he has enjoyed the comforts of life in the Castle. Reiger is happy with his anecdotes at meeting world leaders and receiving gifts from them. Reiger is also worried that the immersion in this indulgent life has taken him away from the view of the common man. Following the interview Reiger is in conversation with a groundsman about the success of the villa's crops. The conversation then turns to Reiger's request for information regarding

\footnotetext{
${ }^{13}$ Williams, Václav Havel.
} 
his relevance on the street. 'Are there any demonstrations about me?” he asks. The worker responds that people are talking about his future move out of the office.

To be clear, I am not building up the case that Havel was an especially vile character. It is important that these admissions of vice possession are read alongside Havel's insistence that politics is a moral affair. The Havel that enjoyed living in the presidential castle is the same Havel that believed in honest politics. The two are not irreconcilable with each other. In revealing his vices Havel, although not heroic, is being honest. The presentation of Reiger as a vain man with the corresponding criticism of that vanity that the film affects is a vivid depiction of Havel's continued project of self-reflexive self-criticism that accompanies his writing on a life in truth. A life in truth, for some commentators, is a courageous standing up to ideological coercion. This is only half correct. Havel's understanding of living in truth is better understood as a constant vigilance over one's own behavior. Havel's critique of post-totalitarian society reveals the extent to which a ruling regime may find that it has an outpost in each citizen. That is each citizen contributes to the sustenance of an ideology's power through accumulation of behaviors which allow its power to thrive. Living in truth, as a challenge for the individual is thus not a call to arms, where each citizen is to reflect on how they can challenge the regime, rather the individual is to reflect on which of their own behaviors helps keep the current situation in power. The idea that living in truth is a continued vigilance over one’s own behavior, as opposed to valorously acting for regime change is on vivid display in Havel's final book, To the Castle and Back. Havel, reflecting on an evening spent at the White House, writes,

Many of the guests told me I was their hero, that they had read my speeches and essays and seen my plays. I never know exactly how to respond to this. Yesterday I tried to explain to several of the guests that if I seem to be a hero it’s certainly not because I ever set out to be one. It was only a long series of circumstances , or dilemmas that provided the setting in which I had to make certain decisions....

I used that explanation to mask my embarrassment. America is fond of stories with heroes and happy endings. I find that endearing. But perhaps Mr. Hvížd’ala is right to suggest that I was 
pushed into hard into this positive role. Yet who among us has never, from time to time, been forced into playing some role? The important thing is to be conscious of that role and to be able to reflect upon it and one's relationship to it.

I must add one more thing: not only was there salt on the table in the White House, but the food was excellent. It bore no resemblance to the tasteless American cuisine that one finds everywhere here. It was a pleasant evening, but later when I got home I was afflicted by coronary fibrillations or arrhythmia. ${ }^{14}$

Havel's response to his admirers is that his behavior, rather than heroic, was an honest commitment to principles, which circumstance gave publicity too. Following his humble assessment of his life's trajectory Havel reflects on the importance of being vigilant in reflecting on how the performance of our social roles affects a social situation. Havel is admitting that luck has played a large role in his successes; however, the important consideration is not the consequences of his decisions but the rigorous selfreflection which helps him remain constant with his principles. This short diary entry concludes with classic Havel self-deprecation. Just as we read Havel assert the importance of a life in truth, Havel resists the reader attaching any heroic connotation to the author by sharing his mundane enjoyment of the food at the White House and the corresponding health problems from the evening. Havel is reminding us, through his self-deprecation that it is the idea of self-reflection, and not the mouthpiece which announces it, which is worth reading.

Havel's enthusiasm for self-deprecation is counter to a strong messianic undercurrent in Czech culture. Robert Pynsent describes the celebration of martyrdom in Czech history and culture stretching back to the mythology surrounding King Wenceslas. ${ }^{15}$ Pynsent's analysis reveals the repeated phenomenon of citizens organizing around the blood sacrifice of dissidents. Self-immolating protestors were celebrated by citizens who brought wreaths to the site of the political suicide. Havel's continued

\footnotetext{
${ }^{14}$ Havel, To the Castle and Back, 86

15 Pynsent, Questions of Identity, 190
} 
revelations of personal impropriety, bodily malfunction, personal indulgence and self-doubt represent a strong attempt to resist an interpretation of political rescue that requires a messianic figure to lead society to its rescue.

In the post-truth world, this anti-heroic thrust is of vital significance for understanding Havel's thoughts on resistance. Unfortunately, it is a point which is often overlooked in Havel scholarship. Essentially what Havel achieves through the presentations of his foibles is a revelation of the complexity of social reality. Much contemporary theory works through the operation of a radical epoche that condenses a political moment to the status of an event. That is, to analyze a form of oppression, individual's lives are conceptually reduced their experience in the event. The political moment is construed as the formal structure of the world and thus subjects contained in this structure discern responsibility in the framework of this structure. Havel's description of the subject is multi-layered. The term 'horizons', borrowed from his phenomenological forbears Husserl and Patočka, is employed by Havel to suggest that a subject's consciousness is only ever in a singular situation when it chooses to ignore the myriad of relationships that coexist simultaneously. That is, the subject acts in a host of simultaneous horizons: one’s immediate surroundings, one’s network of friends, one’s immediate political situation, regional situation, and global situation. In each of these horizons, individuals have influence and responsibilities, and, of course, each horizon could potentially act upon another. Reducing one's responsibilities to one of these horizons ignores the complexity of responsibility and the magnitude of self-reflection required to really behave responsibly.

\section{The Issue with Messianic Resistance}

The significance of conceiving responsibility in terms of horizons is made clearer if we compare Havel's position to that of Alain Badiou, Slavoj Žižek and Georgio Agamben, thinkers whose thought I take as emblematic of philosophers who treat resistance as a messianic phenomenon. Badiou, responding to the Arab Spring uprisings of 2011, argues that the street protests that characterized the events contain echoes of Europe’s 'Spring of Nations' rebellions of 1848. By linking the Arab Spring to a series of rebellious nineteenth century uprisings Badiou describes the structural form of uprising as such. The Arab Spring can thus be construed as an 'event'. That is, the protests across the middle-East are given 
theoretical formal structure which, for the participants, brackets off their involvement in any other activity at the time (such as education, work, care of family etc.). The protestor, as a part of the structure of the riot, is a rioter. Any other 'role' is not conceivable in terms of the event and thus not worth consideration. For Badiou, the riot reopens history by creating a rupture with the politically determined order of things. The rioters say no to the status quo and in that violent stand make great political change possible.

Badiou, using the 2011 Egyptian uprising as his example, explains the significance of the riot as an event.

In a world structured by exploitation and oppression masses of people have, strictly speaking, no existence. They count for nothing. In today’s world nearly all Africans, for example, count for nothing. And even in our affluent lands the majority of people, the mass of ordinary workers, basically decide absolutely nothing, have only fictional voice in the matter of decisions that decide their fate...

Let us call these people, who are present in the world but absent from its meaning and decisions about its future, the inexistent of the world. We shall say then that a change of world is real when an inexistent of the world starts to exist in the same world with maximum intensity. This is exactly what people in the popular rallies in Egypt were saying and are still saying: we used not to exist, but now we exist and we can determine the history of the country. ${ }^{16}$

For Badiou only the political voice matters. The citizen in the age of neoliberal politics is a mere consumer who in a sense does not exist because of their lack of political agency. This is quite a strong claim as to not exist is to be nothing. The citizen quite clearly is something and so we must interpret Badiou's claim as an acerbic epoche that venomously closes off conscious experience to all that isn’t political. That is for Badiou, if we are not being political then we are without meaning. This radical view is what leads Badiou to the conclusion that only violent resistance which ruptures with the everyday

\footnotetext{
${ }^{16}$ Badiou, The Rebirth of History, 55-56
} 
given world can be considered as meaningful resistance. As Erzsébet Kerekes notes, for Badiou, “[t]he subject is defined by his loyalty the Event”. ${ }^{17}$ Outside of the riot, the individual loses their meaning, or in Badiou's terms, they lose their existence.

Slavoj Žižek, Badiou’s student, continues the motivated ignoring of non-political activity, in his pronouncement of support for Donald Trump. In an interview with Al Jazeera Žižek claims,

In this situation in which we are now, only some kind of a shakeup can save us... And one good thing about Donald Trump - and it's an obscenity to call this a good thing - is that he put [the system] into great disarray; it almost fell apart. ${ }^{18}$

Trump is thus for Žižek an instigator of rebellion. He is something to rebel against and as a motivator of political action the preferred political leader. This logical follow on from Badiou's thoughts on resistance has dangerous consequences. Badiou and Žižek are unable to see the meaningful suffering of individuals who could be characterized as inexistent. It is undeniable that, in the age of Trump, oppressed individuals, who for Badiou don't even possess political agency at the voting booth as democratic elections are a sham, are facing an increase in suffering due to a change in the concrete circumstances of their social life. There lives, in my reading, would be drastically improved if concrete issues regarding their everyday life were addressed. Thus, resistance, if it is to be meaningful must be an address to these social changes rather than an ideological attempt to generate political agency as if that were all that mattered. What good is political agency if one does not, for example, have health care or education?

Georgio Agamben’s thoughts on messianic resistance demonstrate just how inadequate messianic thought is for addressing the political problems of today. Agamben's thought is focused on the possibility of a total shift of human activity into another world. Like Badiou, Agamben sees great significance in a rupture with the everyday that offers the possibility of moving into different metaphysical existence. An important concept for Agamben, from the Jewish Apocalyptic tradition, is the notion that there are two worlds and two times - the time and world from creation to resurrection and the coming world of

\footnotetext{
$17 \mathrm{Ibid}, 41$.

18 Zizek, "Electing Trump will Shake up the System".
} 
atemporal eternity. The messiah brings the focus of time in this world (between creation and resurrection) towards its end. That is the messiah shows the relationship of eternity to each moment in the more profane experience of time. To expand on this idea considering the politics of the post-truth world we might criticize Agamben by suggesting that the address to real political problems is to argue for a figure who demonstrates the possibility of complete and total rupture with this world as it is now. The issue with such politics is, as it is in Badiou's work, that this political moment is reduced into a total experience that ignores all else. There is, for Agamben, through the device of the messianic which refocuses the now against the backdrop of eternity, an uncontextualized now, in other words a heaping together of the manifold experiences of social life, which contains, through the messiah the promise of a judgement on our past which allows us to let go of this past and face the future. This critique is shared by Phillippe Mesnard who argues that in abstracting sites of oppression and thereby conflating them as the paradigm of political space the important historical context is lost. ${ }^{19}$

Importantly, we must note that unlike Badiou, Agamben's use of the messianic is not, as Antonio Cimino notes, an attempt to revolt against social conditions. ${ }^{20}$ Instead, Agamben’s political messiah demonstrates how one can reframe the experience of political oppression. Agamben writes,

The Messianic vocation is not a right, nor does it furnish an identity; rather it is a generic potentiality that can be used without ever being owned. To be messianic... signifies the expropriation of each and every juridical-factical property... under the form of the as not. ${ }^{21}$

Through the messianic, political identities which create a division between individuals (e.g. them/us relations) are resisted. Agamben's identification of the homo sacer individual, an individual who cannot be sacrificed by virtue of their extra legal/political status demonstrates his diagnosis of the modern malaise. Where Badiou sees those without agency as inexistent, Agamben is concerned about the extent to which sovereignty excludes individuals from political participation. The rupture which Agamben

\footnotetext{
${ }_{19}$ Messnard The Political Philosophy of Giorgio Agamben, 155.

${ }^{20}$ Cimino, “Agamben's Political Messianism”, 106.

${ }^{21}$ Agamben, The Time that Remains, 26.
} 
hopes for though is achieved through embracing one’s powerlessness. Cimino describes this passivity in Agamben’s understanding of the messianic, “[m]essianic life is revolutionary precisely because it gives up any attempt to destroy the established order of social and political relationships. ${ }^{22}$ For Agamben, the messiah resists the oppressive force of sovereignty through a radical passivity. Just what this means is unclear as Agamben's powerless are distanced from power, the messianic is the realization of pure potentially.

The limitations of Agamben's thinking have been well criticized by Brian Elliott. Absolute powerless, for Elliott, is “ideological fiction” where "it is hard not to see in [the idea] a grotesquely simplified allegory of contemporary reality."23 That resistance today should be aimed at multiple sources of oppression and not some abstracted political-theological sovereign is demonstrative simply by exploring the multiple sites of simultaneous oppression. The myriad of causes to which I can act in the hope of social improvement are diminished if I consider them as the conglomerate of state sovereignty. For example, in contemporary Australia, where I am currently situated I am concerned about refugee rights, the demonization of Islam, the radical othering of Indigenous Australians and a host of other issues requiring attention as well as issues in foreign politics. Furthermore, I am concerned at the increasing encroachment of destructive neoliberal policies which erode any existing social institutions which have the potential to address social issues. Consequently, the idea that my options for responding to these issues are to either riot, or mimic the stateless camp detainee really limit any possibility of effecting positive social change. Furthermore, these examples of messianic resistance are symptomatic of a fascination and overindulgence in using the concept of violence to illuminate questions posed in much contemporary European philosophy and which are well critiqued in Ann Murphy's Violence and the Philosophical Imaginary. ${ }^{24}$ To only see the phenomenon of the riot, or hyper-oppression when looking at humans is to overstate the importance of violence for understanding identity.

The over simplistic view on resistance stemming from the embracement of the disparate understandings of the messianic in Badiou and Agamben are both illustrated in the literary example of

\footnotetext{
${ }^{22}$ Cimino, “Agamben's Political Messianism”, 112

23 Ibid, 268.

${ }^{24}$ Murphy, Violence and Philosophical Imaginary, 1-4.
} 
rioting in Sunil Yapa's novel, Your Heart is a Muscle the Size of a Fist. ${ }^{25}$ The novel is set in and around the 1999 Seattle protests against the World Trade Organization's summit. Yapa does a good job at describing the differing motivations of participants in the riot. Some are there to impress women they are attracted to, others by chance, some are there to show their displeasure at the neoliberal state, others are there for the experience of chaos, while others are there out of curiosity. Yapa avoids describing the riot itself, as the setting for the plot, as being a metaphysical construct. Instead the protest is described as a series of interconnected actions that occur alongside actions which are not a part of the protest. Some characters leave the site of protest and act to achieve goals important to their well-being and which are unrelated to the protest. Furthermore, Yapa’s protest is the setting where the central character Victor, a prodigal son, reconnects with his estranged father, a police officer. Tragically the protest is also depicted as a barrier to positive social change as another central character, Sri Lankan diplomat Charles Wickram, is prevented by protestors from getting an important trade document signed. This document is the only concrete plan for creating a positive social outcome described in the novel and it is prevented through the rupturing of the ordinary world that is affected by the riot. What Yapa achieves is an allegorical depiction of a riot which shows the folly in assuming that, as a moment in history, the riot is able to be abstracted into a phenomenon that brackets off other simultaneous social spheres and assumes the totality of experience. The novel's protagonists are not defined by the setting of the riot in which they find themselves, they act within it, but also act out of it. There motivations are multi-layered and not even obvious to themselves. That is, the novel resists reducing time to the experience of the riot with the result of lampooning the idea of a messianic time which promises to give a glimpse of eternity surrounding the riot. The protagonists have goals outside of the riot which frame the riot as an attempt to make positive concrete changes so those goals can be satisfied.

\section{Havel's alternative to Messianic politics}

${ }^{25}$ Yapa, Heart is a Muscle. 
Havel's resistance which promotes individual reflection on one's actions is as timely as ever and is especially relevant as a response to the messianic theories critiques above. The previously discussed models of resistance offer a view of political renewal heavily dependent upon the idea of a messianic savior. Brimful of the imaginary of violence they are unable to conceive of political progress without violent struggle. When we focus specifically on Havel's self-deprecation there is on vivid display a possibility of thinking about political renewal in dark times without employing an imaginary of violence.

Ann Murphy, employing the insight of Michèle Le Dœuff that the common images that philosophers use to illustrate their theories has a defining effect $\mathrm{n}$ the theory itself, critiqued the use of violent imaginaries in the work of many European philosophers. Murphy is also critical of the imaginary surrounding the use of the term 'vulnerability’. Vulnerability arises quite often in Havel's oeuvre, especially in moments where he is writing of his moral failures and so it is worth pausing on this point. Murphy contends that the use of vulnerability as a concept for grounding ethical politics opens up too many ambiguities about what that vulnerability means that abstract from the concrete reality of a political situation to the extent that for Murphy, "there is nothing necessarily normative or ethically prescriptive in pointing to vulnerability as an intrinsic dimension of embodied life." ${ }^{26}$ Havel is not writing about vulnerability in the feminist tradition and so when he uses the term we must loo towards the use of term by Emmanuel Levinas for a close comparison. Havel does not use vulnerability as a label to describe a group of oppressed persons, instead Havel is using the term to highlight something about the basic human condition of every individual. Vulnerability, as it is in the thought of Levinas, a thinker who Havel had great admiration for, is a mode of comportment towards the other for Havel that allows ethical relations. ${ }^{27}$ This understanding of vulnerability, as a comportment towards others does not have the issue ambiguous relationship between aggression and vulnerability that Murphy problematizes. Vulnerability is a means of cultivating a kind of scepticism in totalising determinations of others. That is Havel's recognition of his own limitations is a way of ensuring that he does not place to much emphasis in his own judgements of others.

\footnotetext{
${ }^{26}$ Murphy, Violence and Philosophical Imaginary, 72.

${ }^{27}$ Havel, Letters to Olga, 325.
} 
The important point in this is that Havel's focus on individual behaviours demonstrates his conviction that political renewal is not found in messianic actions but rather than behaviours which add to the robustness of the political sphere. For this very reason, commentators have made much of the strong affinity between the thought of Havel and Hannah Arendt. ${ }^{28}$ Yet Havel, unlike Arendt does theorise the components of pollical activity as his attention is directed squarely to what constitutes responsible action. Whereas the public and private spheres in Arendt's thought are quite distinct; in Havel the question of ethical action and political renewal is a question for the kitchen table as well as for public institutions like the media, courthouse, or streets for example.

That Havel offers a non-violent and non-messianic means of promoting political renewal can be demonstrated through an analysis of Havel's most famous allegory - of the greengrocer and his placard. In his essay 'The Power of the Powerless' Havel describes the actions of a greengrocer who decides not to place a placard with a socialist slogan in his window alongside the vegetables. ${ }^{29}$ It is important that the character of this allegory is not a hero on the precipice of greatness, he is an ordinary individual facing a small struggle that every other citizen similarly faced. In Havel's allegory that individual chooses not to place the placard and it is tru that he thereby risks a lot of his comforts for making such a provocative decision. It thus might seem like Havel is suggesting that the ethical action is messianic resistance; however the focus of the essay is not on the consequences of the action, nor is it related to a duty to resist. Instead, and this is the often overlooked meaning of the allegory, the greengrocer does not place the placard because the idea of further collaboration is too distasteful to stomach. The greengrocer could be collaborating in a host of overlooked ways, yet in this moment he is aware that his identity is not caught up in the meaning of the slogan and chooses not to place it. Havel suggests that the action is not heroic, but rather the recovery of identity and dignity. ${ }^{30}$

Political renewal is thus a project for individuals who exist in a space with other individuals, it is not an exercise in finding solace in messianic gestures. It is important to note that political renewal has not come through the election of any leader in recent times. One might find Barack Obama to be a preferable

\footnotetext{
${ }^{28}$ See for example, Popescu, Delia. Political Action in Václav Havel's Thought. (Maryland: Lexington Books, 2011).

${ }^{29}$ Havel, 'Power of the Powerless', 27.

30 lbid., 39.
} 
President than Donald Trump; but the reality remains that under Obama race relations in the united states did not improve, security interference in everyday life increased and the lot of the average person declined. ${ }^{31}$ There is little point for messianic dreaming when, as Havel's self-deprecating efforts show, society is made up of people too willing to cast their sovereignty to some leviathan who removes them of responsibility for ensuring a robust civil society. ${ }^{32}$ This is the real meaning of the power of the powerless, it is not so much a text about standing up to authority but a text which demonstrates just how little can be hoped for from authority. The greengrocer does not place his protest because he hopes that by doing so a cain reaction will lead to revolution, rather Havel places the focus squarely on the greengrocer's distaste for acting otherwise. Havel is thus moving the debate about resistance away from discussions of moments of opposition, and more towards something like virtue theory.

Hence in demonstrating the real relevancy of Havel to contemporary debates about resistance it is important to note that Havel was as critical of Western politics as he was of socialism. For Havel, any situation which hinders self-reflection is problematic. ${ }^{33}$ Žižek has criticized Havel for supposedly being hypocritical in his support of Western politics. ${ }^{34}$ For Žižek, Havel’s position reveals the way that any attempt at change becomes a tool of capitalist ideology at sustaining itself. That is Havel, in Žižek’s reading, co-opts resistance into support for capitalism.

This, then, is Havel's tragedy: his authentic ethical stance has become a moralising idiom cynically appropriated by the knaves of capitalism. His heroic insistence on doing the impossible (opposing the seemingly invincible Communist regime) has ended up serving those who 'realistically' argue that any real change in today's world is impossible. This reversal is not a betrayal of his original ethical stance, but is inherent in it. The ultimate lesson of Havel's tragedy is thus a cruel, but inexorable one: the direct ethical foundation of politics sooner or later turns into its own comic caricature, adopting the very cynicism it originally opposed. ${ }^{35}$

\footnotetext{
${ }^{31}$ See for example, James Grossman In Time Staff, "10 Historians on What Will Be Said About President Obama's Legacy" In Time Magazine, Jan 20, (2017), http://time.com/4632190/historians-obamas-legacy/

32 Havel, "Power of the Powerless" 37.

${ }^{33}$ Havel, Summer Meditations, 60.

34 Žižek, "Logic of Capitalism" 6.

35 Ibid, 6.
} 
Of course, I disagree with Žižek’s cynicism; but there is something important in his summation of the change in the perceived value of Havel's thought. Havel, as far as he is remembered as a fighter against totalitarian politics, has been co-opted in the attempt to return politics to how it was before Trump's victory. This ignores the level of criticism that Havel levelled at yesterday's politics as well as the potential for critique today. An important point in Havel's thought regarding the horizons of responsibility is to consider what are the micro behaviours between friends and colleagues which set the foundations of the social sphere upon which Trump succeeded. Those behaviours, for Havel, are what need to be reflected upon and resisted. Havel, in arguing for personal resistance against ideology is demonstrating the non-ideological component of personhood - that part of identity which is encountered in self-reflection. The danger here is that Havel might have left himself open to interpretation as a Messianic fighter struggling for the return of business-as-usual capitalism (which is how Žižek interprets him). What Žižek misses is that the moral dimension to politics that Havel identified is not a support for democratic politics as such; instead this moral dimension has no attachment to any political system. Havel is only concerned about the impact that individual actions between friends have in creating a political situation - once that horizon is properly considered then and only then should one have concern for the type of system one lives in. Havel, in Summer Meditations, the first book written during his Presidency, summarizes the importance of self-reflection as the basis of moral politics rather than promoting a struggle for a particular political system.

What can I do, as president, not only to remain faithful to [a moral] notion of politics, but also to bring it to at least partial fruition?...

As in everything else, I must start with myself. That is: in all circumstances try to be decent, just, tolerant, and understanding, and at the same time try to resist corruption and deception. ${ }^{36}$

\footnotetext{
${ }^{36}$ Havel, Summer Meditations 6-7
} 
This sentiment is throughout Havel's intellectual life. In Kieran Williams' intellectual biography of Havel the lasting influence on Havel from his early encounter with the thought of Pavel Šafařík is made clear. Williams explains that,

Since the moral 'scaffolding' and 'balustrades' that modern man constructed had clearly failed, Šafaŕík advocated a radical individualism of active participants following the voice of conscience... ${ }^{37}$

This insight from Havel's first major philosophical influence can be discerned throughout Havel's writing. He never deviates from advocating such an individualism.

Jeffrey Goldfarb outlines the real significance of Havel's resistance in his book, The Politics of Small Things. For Goldfarb, Havel's key insight is the effect that our seemingly non-political actions have on a social situation. Hope for a positive change in social situations is found in paying attention to these smaller interactions. Building on Havel's notion of the power of the powerless, Goldfarb writes,

The politics of small things is about creating [zones of independence and dignity]. It's the independence that matters, not the size... In the life of ongoing social institutions and in the forging of social movements, zones of political freedom and creativity are constituted in social interactions and we must pay attention. ${ }^{38}$

Havel is not seeking to promote an ideology of democratic freedom to replace an ideology of oppression. Rather Havel's focus is always on how individuals present themselves to each other. Goldfarb identifies that for Havel the fate of the regime is tied not to the ideology that people act for, but to the level of care people display in their social interactions. I have elsewhere provided illustrative support of Havel's notion of the power of the powerless in Victor Klemperer's diaries which detailed the change in ordinary

\footnotetext{
${ }^{37}$ Williams, Vaclav Havel, 38

${ }^{38}$ Goldfarb, Politics of Small Things, 68
} 
language usage in Dresden during the Third Reich. ${ }^{39}$ The point from this is that Klemperer's diaries demonstrate how a non-reflective public adopting changes in conversational language which normalize prejudiced attitudes, create the social conditions in which the acting out of that prejudice is allowed. Thus, resisting any perceived 'evil' in a social situation is a matter between individuals.

Thus Havel, as a resistance figure, is not the messianic answer to our ills. In the post-truth age Havel's significance is not to show how a system might be resisted but to challenge individuals to reflect on their own behavior and to see how they might have helped in the creation of the conditions in which post-truth politics has thrived. Political categories such as ‘democracy’ or even 'liberalism’ are inadequate for repairing the broken social scene and no politician should be looked for to replace an evil one with good systemic change. Instead the politics of small things contained in the power of the powerless is timely precisely because it challenges us to ignore radical solutions and become virtuous people. Post-truth politics cannot survive in society where people are authentic in their interactions with others. Havel writes,

To shed the burden of traditional political categories and habits and open oneself up fully to the world of human existence and then to draw political conclusions only after having analyzed it: this is not only politically more realistic but at the same time, from the point of view of an 'ideal state of affairs', politically more promising as well. A genuine, profound, and lasting change for the better - as I shall attempt to show elsewhere - can no longer result from the victory (were such a victory possible) of any particular traditional political conception, which can ultimately be only external, that is, a structural or systemic conception. ${ }^{40}$

Havel continues,

\footnotetext{
${ }^{39}$ Brennan, "Public Private Dichotmoy".

${ }^{40}$ Havel, Power of the Powerless, 52
} 
A better system will not automatically ensure a better life. In fact, the opposite is true: only by creating a better life can a better system be developed. ${ }^{41}$

Havel's challenge is to look outside of ideology for answers to concrete problems, not to analyze concrete problems as ideological ones. If window ledges are falling and injuring people we should ask that they be repaired, not hope for a total shift in the fabric of social relations. They are repaired when citizens can recognize that phenomena with ideological inflections generally have a concrete foundation that exists apart from its ideological identity. Such realizations empower individuals to act to fix that problem - this is the essence of Havel's resistance.

\section{Bibliography}

Agamben, Georgio. The Time that Remains; A Commentary on the Letter to the Romans. Translated by Patricia Dailey. CA: Stanford University Press, 2005.

Badiou, Alain. The Rebirth of History; Times of Riots and Uprisings. Translated by Gregory Elliott. London: Verso, 2012.

Ben-Ghiat, Ruth. “Donald Trump’s Authoritarian Politics of Memory” The Atlantic, January 22, 2017. Accessed February 1, 2017, https://www.theatlantic.com/politics/archive/2017/01/donald-trumpsauthoritarian-politics-of-memory/514004/

Ben-Ghiat, Ruth. "Trump is following the Authoritarian Playbook” CNN, January 17, 2017, Accessed February 1, 2017, http://edition.cnn.com/2017/01/16/opinions/trump-following-authoritarianplaybook-ben-ghiat/

Bilefsky, Dan. "Václav Havel Refused 1991 Nobel Peace Prize Nomination, Says Daw Aung San Suu Kyi” The New York Times. September 16, 2013. Accessed February 2, 2017. https://thelede.blogs.nytimes.com/2013/09/16/Václav-havel-refused-1991-nobel-peace-prizenomination-says-daw-aung-san-suu-kyi/?_r=0

\footnotetext{
${ }^{41} \mathrm{lbid}, 52$.
} 
Bradner, Eric. “Pelosi: Trump’s Obama claim an ‘Authoritarian’ Tactic” CNN, March 6, 2017, Accessed March 8, 2017, http://edition.cnn.com/2017/03/05/politics/nancy-pelosi-trump-authoritarian/

Brennan, Daniel. “Considering the Public Private-Dichotomy: Hannah Arendt, Václav Havel and Victor Klemperer on the Importance of the Private” Human Studies. 2017. doi:10.1007/s10746-017-9424-x

Cimino, Antonio. Agamben’s Political Messianism in ‘The Time that Remains’ International Journal of Philosophy and Theology. 77, no. 3, 2016: 102-118

Goldfarb, Jeffrey. The Politics of Small Things: The Power of the Powerless in Dark Times. Chicago: Chicago University Press, 2006.

Gray, John. Black Mass; Apocalyptic Religion and the Death of Utopia. London: Penguin Books, 2007. Havel, Václav, et al. “The Power of the Powerless” The Power of the Powerless. Translated by Paul Wilson. New York: Palach Press, 1985.

Havel, Václav. Disturbing the Peace. Translated by Paul Wilson. New York: Vintage Books, 1990. Havel, Václav. Letters to Olga, Translated by Paul Wilson, New York: Henry Holt and Company, 1989. Havel, Václav. Summer Meditations. Translated by Paul Wilson. New York: Vintage Books, 1993. Havel, Václav. To the Castle and Back. Translated by Paul Wilson. New York: Alfred A. Knopf, 2007. Messnard, Philippe. “The Political Philosophy of Giorgio Agamben: A Critical Evaluation” Totalitarian Movements and Political Religions, 5, no. 1, 2004 :139-157.

Mishra, Pankaj. “Václav Havel’s Lessons on how to Create a 'Parallel Polis’” The New Yorker, February 8, 2017. Accessed February 27, 2017. http://www.newyorker.com/books/page-turner/Václav-havelslessons-on-how-to-create-a-parallel-polis

Murphy, Ann. Violence and the Philosophical Imaginary. Albany: SUNY Press, 2012.

Odcházení. Directed by Václav Havel. 2011. Prague: BUC Film. DVD.

Renaud, Terrence. “Going Underground” Aeon, March 14, 2017. Accessed March 15, 2017. https://aeon.co/essays/the-strange-political-history-of-the-underground Robert Pynsent, Questions of Identity; Czech and Solvak Ideas of Nationality and Personality. London: Central European University Press, 1994. 
Salhani, Justin. “Experts in Authoritarianism are very concerned about Trump’s First Few Days as President” ThinkProgress, January 25, 2017. Accessed February 1, 2017, https://thinkprogress.org/afew-days-into-trumps-presidency-experts-see-authoritarian-red-flags-baf2271e3503

Williams, Kieran. Václav Havel. London: Reaktion Books, 2016.

Yapa, Sunil. Your Heart is a Muscle the Size of a Fist. London: Little Brown, 2016.

Zimbardo, Philip. “Why the World needs Heroes” Europe’s Journal of Psychology 7, no. 3 (2011): 402407.

Žižek, Slavoj. “Attempts to Escape the Logic of Capitalism” London Review of Books. 21, no. 21, October 1999: 3-6.

Žižek, Slavoj. “Žižek: Electing Trump will 'shake up' the System” Aljazeera. November 16, 2016. Accessed February 15, 2017. http://www.aljazeera.com/programmes/upfront/2016/11/zizek-electingtrump-shake-system-161116062713933.html 